\title{
Do tiers affect student transfer? Examining the student admission ratio
}

\author{
Gavin Moodie \\ Griffith University, Australia
}

Address correspondence to: Gavin Moodie, 5 Park Road, YERONGA, 4014, Australia. E-mail: Gavin.Moodie@telstra.com.au 
This study considers whether formally segmenting four-year institutions by admissions selectivity affects the admission of transfer students. It develops a new measure, the student admission ratio, to compare the admission of transfer students in formally and highly segmented systems, informally and less segmented systems, and in formally unified systems. The study finds that the segmentation of systems by admissions selectivity does not adversely affect transfer admissions. The study concludes by positing that the formal structure of a system is not so important for student transfer as the processes for implementing transfer policy and considers the implications of this for practice.

Most studies of student transfer in the U.S. consider the rate of transfer from community to four-year colleges, and this is thought to indicate the success of community colleges in at least one of their important roles (Dougherty, 1992; Shaw \& London, 1995; Gelin 1999, p. 4; Striplin 1999; Carlan \& Byxbe 2000; Wassmer, Moore \& Shulock, 2003, .p 21) or to illuminate important characteristics such as their culture and ideology (Shaw \& London, 2001). But transfer rates depend on a range of factors, only some of which can be controlled or even influenced by community colleges. Cohen (2005) lists: 'the proximity to and availability of a neighboring university, existing partnership agreements, collegiate traditions, the extent to which high school counselors and prospective students and their families perceive the college as a desirable place to begin study toward the baccalaureate, and the proportion of university and college faculty who continually work together to articulate their lower-division courses'. As Gelin (1999, p. 11) observes 'Effective transfer is a function of both sending and receiving institutional policies, practices, and culture. Using transfer rates to measure the effectiveness of the sending institution leaves out one half of the equation.'

Many have also observed that students with different backgrounds and aspirations are likely to have different rates of transfer (Grubb, 1991; Higgins \& Katsinas, 1999; Laurente \& Pailthorp, 2002, p. 4; Wassmer, Moore \& Shulock, 2003, p. 3). Some studies seek to control for this by measuring college readiness or preparedness - how adequately students in each state are prepared for education and training beyond high school (National Center for Public Policy and Higher Education, 2002). This shifts attention on transfer from an indicator of the performance of community colleges to an indicator of the performance of their students (Lee \& Frank, 1990). Other studies seek to use as the denominator for transfer rates students who are in transfer programs or who express an aspiration to transfer upon entering higher education (US Department of Education, 2003, p. 44; Bradburn \& Hurst, 2002), but 
even the investigators acknowledge that these are inadequate measures, or at least that the choice of numerator and denominator depends upon the purpose underlying the collection of the information (Gelin, 1999, p. 3).

This study considers student transfer not as an indicator of the performance of community colleges or of their students, but as an indicator of the performance of the system as a whole. In particular, the study considers whether segmenting a system into tiers by selectivity of student admissions affects the rate at which transfer students gain entry to the most selective institutions and tier. Some US states have long formally segmented their higher education institutions. Thus California has segmented its higher education system since its master plan for higher education was enshrined in the Donahoe Act of 1960, and Douglass (2004, p. 11) points out that California had developed three distinct and geographically dispersed and multi-campus public segments as early as 1920. Other states have more recently decided to differentiate their institutions by selectivity of student admissions. As Marble and Stick (2004, p. 354) reported in these pages recently, since 1991 'the Missouri Department of Higher Education has required public four-year colleges and universities to adopt an appropriate level of admissions selectivity from a tiered system of four categories Highly Selective, Selective, Moderately Selective, and Open Enrollment'. In October 2003 the Colorado Commission on Higher Education (2003) significantly augmented its initial admissions standards policy adopted in 1986 to establish categories of admissions standards for its public four-year and community colleges similar to Missouri's which will be applied from 2008, thereby formalizing and systematizing differences in selectivity that had previously been partly established formally and developed informally.

Other states such as Texas do not formally differentiate their institutions but for the purposes of analysis group them according to general academic mission and certain key academic indicators such as size and number of graduate programs, research expenditures and other factors. However, the Texas Higher Education Coordinating Board (2004, p. 1) says that its 'groupings are intended to be neither permanent nor prescriptive. Rather, they are to be considered permeable, subject to revision as institutions evolve and shift their academic missions' (emphasis in original). Yet other jurisdictions formally recognize no distinction between their baccalaureate-granting institutions, although they may allocate them different amounts of general funds or research grants as a historical legacy or by a method in which all institutions ostensibly compete equally.

As Clark Kerr (1994, p. 69) argued 'the principle of selectivity is central' to the structuring of higher education. Institutions' decisions on the admission of students determines which students have and which students do not have the opportunity to benefit from their programs. This in turn shapes students' occupation, prestige and life chances as 
Clark (1983, p. 63) observed, and indeed, it affects students' income earning potential for the rest of their lives. Tiered selective admissions clearly affects enrollment patterns, although not necessarily in expected ways (Marble \& Stick, 2004). If it also affects the admission of transfer students it would have important implications for policy.

\section{METHOD}

One possibility would be to compare the admission of transfer students before and after a change in admissions policy. This has three difficulties. First, major changes to admissions policy need a long lead time to implement and take some time to affect student transfer. Thus Colorado's decision in 2003 to establish categories of admissions standards will be implemented from 2008, and it wont be until some years later that system-wide data is available to measure its effect. Secondly, policymakers wish to know the implications of various options before they take a decision, not several years after. By the time a post hoc evaluation has been completed it is often too late to reverse the decision and return to the previous policy. Thirdly, several other changes may occur contemporaneously with the change in admissions policy and thus confound any attempt to link a change in data to the change in policy being considered, as Marble \& Stick (2004, p. 363) found.

An alternative is to compare different systems' performance over the same period. However, this is usually made very difficult by differences in systems’ definitions of transfer and their data collection methods. As Castañeda (2002, p. 441) observes, numerous scholars and policymakers have lamented the lack of comparable data on student transfer for many years and there is no indication that these pleas are being heeded. Nonetheless, several studies compare transfer rates between states, but this is misleading unless the data are corrected for several differences between states which affect transfer rates but are not the direct outcome of transfer policies or practices. First, the overall participation rate and the participation rate in each segment must be considered. A state with a very high proportion of its population participating in four-year colleges is likely to have a lower rate of transfer from community colleges than a state which has high participation in community colleges and a much smaller proportion of students enrolled in four-year colleges.

Secondly, a range of state-wide inhibitory and facilitative factors needs to be considered such as geographic access and financial factors (Alkin \& Hendrix, 1967). Thus, most community college students study part time while commuting from home or work and are unlikely to seek to transfer to a college which is beyond convenient commuting distance (Laurente \& Pailthorp 2002, p. 4). Yet ready access to a four-year college can have as much to do with a state’s geography and population density as to its higher education structure and policies. A state which 
has a higher proportion of community college students from low socio economic status backgrounds is likely to have a lower transfer rate than wealthier states since students from low socio economic status backgrounds are more discouraged by financial barriers than others and have less cultural capital to negotiate complex or technical admission or transfer requirements.

Correcting for all of these factors makes the comparison of transfer rates very complex. To overcome this difficulty a new measure has been developed, the student admission ratio. Consider a hypothetical system in which its highly selective four-year institutions have a total freshman class of 1,000 students. If 50 freshmen are transfers from two year colleges transfers would be five per cent of the freshman class. If the system's moderately and less selective four-year institutions admitted 1,000 transfer students in a freshman class of 10,000, transfers would be ten per cent of the class. In this system the highly selective institutions admit half the proportion of transfer students (5\%) as the moderately and less selective institutions (10\%), and thus the transfer student admission ratio is 1:2. Compare this with a second system where reported transfer is overall much higher and where the highly selective institutions admit 66 transfer students out of a freshman class of 1,000 but the moderately and less selective institutions admit 2,000 transfers out of a total intake of 10,000. In the second system the transfer student admission rate at the more selective institutions is 6.6 per cent and the rate at the less selective institutions is 20 per cent. The ratio between the transfer student admissions rates in the second system is 1:3, considerably higher than the ratio of 1:2 in the first system. Thus the more selective institutions in the second system admit relatively fewer transfer students than the more selective institutions in the first system, notwithstanding that in the second system the more selective institutions admit more transfer students and state-wide transfer is relatively higher than in the first system.

The higher transfer rates reported in the second system may be an artifact of the system's broader definition of transfer but the student admission ratio is a measure of relative performance within a system, and so treats each institution within a system equally in the system's own terms. Comparing relative performance within a system also makes it unnecessary to account for many of the other differences between jurisdictions and systems. We are thus able to compare the relative performance of quite different systems and jurisdictions. Comparing transfer student admission ratios for formally segmented systems, informally segmented systems and formally undifferentiated systems allows us to test whether segmenting a system into tiers by selectivity of student admissions affects the rate at which transfer students gain entry to the most selective institutions and tier. One might hypothesis that transfer 
student admission ratios are higher and that therefore transfer admission is relatively harder in the formally segmented systems. However, this study provides little if any support for that hypothesis.

\section{RESULTS}

California divides its higher education institutions into three segments: the University of California whose intake is restricted by legislation to the top $12.5 \%$ of high school graduates, the California State University whose intake is restricted to the top 33.3\% of high school graduates, and California Community Colleges, which have open admission. The California Postsecondary Education Commission $(1998,2000)$ reports that in 1998-99 a total of 59,906 students transferred from the California Community College system to California universities. Since there were 1,304,554 students in the California Community College system in 1996, approximately $4.5 \%$ transfer to higher level studies in the same state each year. A total of 10,161 transferred to the University of California. The University of California enrolled 155,412 undergraduate students in 1996, so California Community College transfer students comprised $6.5 \%$ of the University of California's total undergraduate student population. A total of 44,989 California Community College students transferred to California State University system. This system enrolls 336,803 undergraduate students, so $13 \%$ of its students transferred from California community colleges. These figures are tabulated below.

$<$ Insert Table 1 here $>$

Community College transfer students were $6.5 \%$ of students at the highly selective University of California but were $13 \%$ of students at the moderately selective California State University, giving a ratio of 1:2 between the two segments. This is shown in the next table.

$<$ Insert Table 2 here $>$

Some 59\% of Colorado's higher education students start in four-year institutions, much higher than the US average (45\%) and very much higher than in California (34\%), so there are fewer students in community colleges seeking to transfer to four-year institutions in Colorado. Overall transfer student admission rates are therefore lower in Colorado than in California.

$<$ Insert Table 3 here $>$

Colorado did not formally designate four-year institutions by selectivity of admissions at the time the data for this study were collected. However, the Colorado Commission on Higher Education (2003a, p 10) analyzed 
institutions' selectivity to inform a new admissions standards policy from which it was possible to identify Colorado's highly selective four-year colleges as the Colorado School of Mines, the University of Colorado Boulder and Colorado State University. Transfers were 3\% of enrolments at the highly selective institutions and 6\% of students at the moderately selective institutions. Despite Colorado's lower overall transfer student admission rate than California's, which may be partly due to differences in data definitions and collection methods in addition to the other factors considered, the differences in transfer student admission rates between Colorado's highly selective and moderately selective receiving institutions is the same as in California.

$<$ Insert Table 4 here $>$

Texas does not have an explicit policy of distinguishing public four-year colleges by selectivity of student admissions. A measure of the selectivity of institutions is the proportion of their first-time undergraduates who were in the top $10 \%$ of their high school class and this was used to classify institutions as highly and moderately selective.

$<$ Insert Table 5 here $>$

Texas has a very strong transfer policy and consequently its four-year institutions have twice as many transfer students as California. But again, the different transfer student admission rates between highly selective and moderately selective four-year institutions is similar to, although a little less than in California and Colorado.

$<$ Insert Table 6 here $>$

These differential transfer student admission rates between highly selective and moderately selective four-year institutions are compared with two jurisdictions which have formally unified systems of four-year or baccalaureategranting institutions: Australia and Scotland. Australia has had a 'unified national system' (Dawkins, 1988) of baccalaureate-granting institutions since 1998. Nevertheless, Australia’s baccalaureate-granting institutions differ markedly by selectivity of student admissions. It is convenient to count as the highly selective institutions the group of eight institutions which win the biggest share of external research grants and which have formed an association (Group of eight, 2003). These are also generally but not exclusively the oldest institutions.

Australian public baccalaureate-granting institutions reported that in 2000 they admitted $6.6 \%$ of their commencing baccalaureate students on the basis of a complete or incomplete technical and further education program which is of two years' duration or less (DETYA 2001). The group of eight highly selective Australian universities reported that they admitted 1,028 students or $2 \%$ of their total commencing baccalaureate students on 
the basis of a tafe qualification. The other Australian universities reported that they admitted 10,308 of their commencing undergraduate students, or $8 \%$ of their total commencing undergraduate students on the basis of a tafe qualification.

Australia also allows a comparison with Prager’s (1993) findings on transfer and articulation within U.S. colleges and universities. Prager surveyed 408 chief executive officers of campuses which Peterson's Directory identified as sponsors of two-year tracks within a college, university or system also offering four-year curricula (Prager 1993, p. 541). She concluded (1993, p. 551) -

It appears that students from some two-year programs within four-year contexts may have as much, if not more, difficulty in 'transferring' within their institutions as do students who begin at a community college and seek to transfer to a senior one. Indeed, the findings explored here suggest that problems with internal student transfer and program articulation may be as pervasive within some institutions sharing a common institutional identity as external ones are for some from different sectors, such as community and senior colleges, that do not.

Australia has five so-called ‘dual sector universities’ which comprise substantial student load in both baccalaureate and sub baccalaureate vocational programs. The average transfer student admission rate for Australian dual sector universities is shown separately in the table below.

$<$ Insert Table 7 here $>$

It will be noted that while the dual sector universities had a higher transfer student admission rate than the group of eight highly selective Australian universities, they had a lower rate than the other moderately selective institutions, thus replicating Prager's U.S. findings in Australia. The next table includes the dual sector universities with the other moderately selective baccalaureate-granting universities. It shows that the difference in the ratio of transfer student admission rates between the highly selective and moderately selective baccalaureate-granting institutions is higher in the formally unified system of baccalaureate-granting institutions in Australia than in the variously formally segmented systems in California, Colorado and Texas.

$<$ Insert Table 8 here $>$

Scotland also has a formally unified university sector, but they are informally grouped by age of establishment: ancient universities (founded before the $19^{\text {th }}$ century), 1960s universities (institutions which had university status before the Further and Higher Education Act 1992) and post 1992 universities (re-designated as universities by the 
Further and Higher Education Act 1992 or founded after the Act). Gallacher (2003, p. 12) reports the numbers and percentages of students entering baccalaureate-granting institutions in Scotland for whom the two-year higher national certificate or diploma was the highest qualification on entry. He reports those for ancient universities (3\%), 1960s universities (8\%), post '92 universities (25\%) and art/music colleges (13\%). Gallacher (2003, p. 11) refers to Maclennan et al's (2000) distinction between selecting and recruiting universities but does not classify universities in his study. The next table was calculated by classifying the ancient and 1960s universities as highly selective universities and the post '92 universities and art/music colleges as moderately selective institutions.

$<$ Insert Table 9 here $>$

These results are summarized in the final table, which is ordered from Scotland and Australia where the difference in transfer student admission rates of the highly selective and moderately selective baccalaureate-granting institutions is relatively high, to California, Colorado and finally Texas where the difference in transfer student admission rates is much smaller.

$<$ Insert Table 10 here $>$

\section{CONCLUSION}

These results suggest three conclusions. First, the formal segmentation of institutions into sectors does not always structure opportunities for students as much as the informal differences between institutions. Clark’s (1983, p. 52) explanation for highly differentiated student admissions practices is that the lack of formal segmentation by tier drives systems to greater internal stratification, which at least in Australia and Scotland is by status which in turn is strongly related to institutional age.

Secondly, the jurisdictions' different transfer student admission rates are at least associated with the strength of their transfer policies and provisions. Since the Australian 'unified national system' of baccalaureate-level education is not formally segmented its internal stratification is tacit, and therefore there is no problem articulated which requires a response from government. While the Australian Government issued general guidelines for the transfer of credit between the sectors that existed until 1988, since the subsequent unification of the sectors there has been no such provision for transfer from non-baccalaureate to baccalaureate-granting institutions. Support for student transfer thus rests on the voluntary and largely individual action of each institution. The Australian ViceChancellors' Committee (no date) has established voluntary guidelines on cross-sector qualification links and gives a list of the programs and institutions covered by the policy (AVCC, 2003). Most institutions participate, but list on 
average only six programs covered by the guidelines, which are a small minority of the several hundred undergraduate programs that each institution offers. Like Australia, Scotland has not formally segmented its universities. While the Scottish Government seems more concerned with supporting student transfer than Australian governments, this concern is relatively recent and has not yet moved much beyond commissioning the studies cited in this paper.

In a study of transfer rates of 97 rural community colleges Higgins \& Katsinas (1999) found that colleges which were subject to legislatively mandated transfer policies had an average transfer rate of $23 \%$ whereas colleges with non binding arrangements had a transfer rate of $14 \%$. Higgins \& Katsinas conclude that 'state policy clearly does matter, and states serious about implementing “seamless” K-16 education systems should seriously re-examine their transfer policies to promote better inter-institutional articulation and transfer'. In a paper on state support for interinstitutional transfer and articulation Welsh \& Kjorlien (2001, p. 329) similarly conclude that 'The priorities and initiatives of state higher education offices and boards profoundly affect the priorities and initiatives of institutions'.

Thirdly, as Prager argued about transfer and articulation within colleges and universities (1993, p. 551-2), even when strong student transfer policies exist they can be thwarted by failure to implement them and by a range of 'transfer-inhibiting practices' such as enrolment caps favoring baccalaureate track students, requiring subbaccalaureate students wishing to pursue the baccalaureate to reapply for admission as if foreign to the institution, and various opaque and discriminatory credit-denying practices. As the California Postsecondary Education Commission (2002, p. 15) argues, these institutional behaviors should in turn be seen within a broader context of system-wide, departmental and faculty characteristics and behaviors.

\section{IMPLICATIONS FOR PRACTICE}

This study developed a new measure, the student admission ratio, which overcomes the incommensurability of admissions data in different systems and thus is useful in comparing jurisdictions. The study divided institutions by selectivity of student admissions, but it would be possible to consider other salient characteristics of institutions such as public/private ownership, high/low resources per student, urban/suburban/rural location, and high/low proportion of students from a low socio-economic status background. While this study applied the admission ratio to transfer students, it could equally be applied to other categories of student admission such as race or socio-economic status. Thus, one could examine whether different state admissions or affirmative action policies affect the rates at which historically black and other institutions admit minority students. 
System-wide decisions and conditions clearly affect student transfer and set the parameters within which institutions and practitioners can act. However, they do not determine outcomes. In particular, this study has found that the segmentation of a system into tiers by selectivity of student admissions does not affect the rate at which transfer students gain entry to the most selective institutions and tier. Cohen (2005) observes more generally that 'transfer rates vary more between colleges within a state than they do between states. And the characteristics of individual institutions are more salient than student demographics; the rate of transfer for ethnic minority students in a high transfer rate college is higher than that of all students on a statewide average'. This suggests that practitioners have considerable capacity to influence outcomes within the framework set by their system.

\section{ACKNOWLEDGEMENT}

I thank Jim Jacobs of the Colorado Commission on Higher Education for providing a data file from his research group on transfers between Colorado 2-year and 4-year higher education institutions.

\section{REFERENCES}

Australian Vice-Chancellors' Committee (AVCC) (no date, 2001?). AVCC policy guidelines on cross-sector qualification

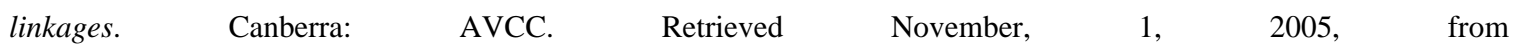
http://www.avcc.edu.au/documents/policies_programs/teaching_learning/credit_transfer/AVCC_Guidelines.pdf

Bradburn, E. M. \& Hurst, D. G. (2001). Community college transfer rates to 4-year institutions using alternative definitions of transfer, Education Statistics Quarterly, volume 3, issue 3 (Fall 2001), http://nces.ed.gov/pubs2002/quarterly/fall/q71.asp

Douglass, J. A. (2004). The dynamics of massification and differentiation: a comparative look at higher education systems in the United Kingdom and California, Higher Education Management and Policy, 16(3), 9-33.

California Postsecondary Education Commission (1998). Factsheet 98-1, composition of higher education in California, http://www.cpec.ca.gov/FactSheets/FactSheet1998/fs98-1.asp

California Postsecondary Education Commission (2000). Performance indicators of California higher education, 2000, Commission report 01 - 3. Retrieved August 11, 2001, from http://www.cpec.ca.gov/completereports/2001reports/0103.pdf

California Postsecondary Education Commission (2002). Student transfer in California postsecondary education, commission report 02-3, http://www.cpec.ca.gov/completereports/2002reports/02-03.pdf

Carlan, P. E. \& Ferris R. (2000). Community colleges under the microscope: an analysis of performance predictors for native and transfer students. Community College Review, 28, 27-45. 
Castañeda, C. (2002). Transfer rates among students from rural, suburban, and urban community colleges: what we know, don’t know, and need to know. Community College Journal of Research and Practice, 26, 439- 449.

Clark, B. C. (1983). The higher education system: academic organization in cross-national perspective, Berkeley: University of California Press.

Cohen, A. M. (2005). Why practitioners and researchers ignore each other [even when they are the same person]. Community College Review, 33, 51-63.

Cohen, A. M. \& Brawer, F. B. (1996). The American Community College ( $3^{\text {rd }}$ Edition), San Francisco: Jossey-Bass.

Colorado Commission on Higher Education (2003). Admissions standards. Retrieved October 31, 2005, from http://www.state.co.us/cche/policy/newpolicies/i-partf.pdf

Dawkins, The Hon J. S., MP (1988). Higher education: a policy statement ('the White Paper'), Canberra: Australian Government Publishing Service.

Dougherty, K. J. (1992). Community colleges and baccalaureate attainment, Journal of Higher Education, 63 (2): $188-214$.

Gallacher, J. (2003). Higher education in further education colleges: the Scottish experience. The Council for Industry and Higher Education, London, http://www.cihe-uk.com/publications.htm

Gelin, F. (1999). Transfer rates: how to measure and for what purpose? A discussion paper, Vancouver: British Columbia Council on Admissions and Transfer, http://www.bccat.bc.ca/pubs/transrates.pdf

Group of eight (2003). About the group of eight, http://www.go8.edu.au/about.html

Grubb, W. N. (1991). The decline of community college transfer rates: evidence from national longitudinal surveys, Journal of Higher Education, 62 (2), pp 194-222.

Higgins, C. S. \& Katsinas, S. G. (1999). The relationship between environmental conditions and transfer rates of selected rural community colleges: a pilot study, Community College Review, 27, 1-27.

Kerr, C. in association with Gade, M. \& Kawaoka, L. (1994). Higher education cannot escape history: issues for the twenty-first century, Albany: State University of New York Press.

Laurente, Z. \& Pailthorp, K. (2002). California’s transfer patterns, http://www.cpec.ca.gov/commission/Agenda0212/Tab_07.pdf

Lee, V., \& Frank, K. (1990). Student characteristics that facilitate the transfer from two-year to four-year colleges. Sociology of Education, 63, 1978-1993.

Maclennan, A., Musslebrook, K. \& Dundas, M. (2000). Credit transfer at the FE/HE interface. Scottish Higher Education Funding Council/Scottish Further Education Funding Council, http://www.sfefc.ac.uk/publications/other/wideopps.pdf

Marble, A. D. \& Stick, S. L. (2004). Admissions selectivity and shifting enrollments at Missouri colleges and universities. Community College Journal of Research and Practice, 28, 353-364. 
National Center for Public Policy and Higher Education (2002). States at a glance: Texas. Measuring up 2002: The state-by-state report card for higher education. Retrieved June 15, 2003 from http://measuringup.highereducation.org/2002/stateglance.cfm

Prager, C. (1993). Transfer and articulation within colleges and universities. The Journal of Higher Education, 64, 5, 539-554.

Shaw, K. M. \& London, H. B. (1995). Negotiating class and cultural boundries: toward an expanded definition of the transfer process. Paper presented at the ASHE Annual Meeting, Orlando, Florida. (ERIC Reproduction Document Service No. ED 391 432).

Striplin, J. J. (1999). Facilitating transfer for first-generation community college students, ERIC Digest, Los Angeles, California: ERIC Clearinghouse for Community Colleges. (ERIC Reproduction Service Document No. ED 430 627).

Texas Higher Education Coordinating Board (2001). Report on the performance of Texas public universities. Retrieved November 18, 2001 from www.thecb.state.tx.us

Texas Higher Education Coordinating Board (2003). Closing the gaps by 2015: 2003 progress report, http://www.thecb.state.tx.us/reports/pdf/0621.pdf

Texas Higher Education Coordinating Board (2004). Accountability in higher education: Promoting excellence in Texas public universities through institutional groupings, peers, and benchmarks. Retrieved October 31, 2005, from http://www.thecb.state.tx.us/ClosingtheGaps/UNIV_Forming.pdf

U.S. Department of Education, National Center for Education Statistics (2003). The condition of education 2003. NCES 2003067, Washington, DC: U.S. Government Printing Office, http://nces.ed.gov/programs/coe/2003/pdf/19_2003.pdf

Wassmer, R., Moore, C., \& Shulock, N. (2003). A quantitative study of California community college transfer rates: policy implications and a future research agenda. Policy issue report. Sacramento: California State University, http://www.csus.edu/ihe/PDFs/02-03.pdf

Welsh, J. F. \& Kjorlien, C. (2001). State support for interinstitutional transfer and articulation: the impact of databases and information systems. Community College Journal of Research and Practice, 25, 313-332. 
Table 1: proportion of students at the highly selective University of California and the moderately selective California State University who transferred from a community college, 1998-99

\begin{tabular}{lccc}
\hline Segment & Number of & Total u/grad & \% of u/grad enrolments who \\
& transfers & enrolments & are transfers \\
\hline University of California & 10,161 & 155,412 & $6.5 \%$ \\
California State University & 44,989 & 336,803 & $13 \%$ \\
Total & 59,906 & 492,215 & $12 \%$ \\
\hline
\end{tabular}

Source: California Postsecondary Education Commission (1998) Factsheet 98-1 
Table 2: ratio of transfer student admission rates of highly selective and moderately selective four-year institutions, California, 1998-99

\begin{tabular}{lccc}
\hline Jurisdiction & $\begin{array}{c}\text { Highly selective } \\
\text { institutions }\end{array}$ & Moderately selective & Ratio of highly selective to \\
& institutions & moderately selective \\
\hline California & $6.5 \%$ & $13 \%$ & $1: 2$ \\
\hline
\end{tabular}


Table 3: proportion of students at the highly selective and the moderately selective four-year public institutions who transferred from a community college, Colorado, 2001

\begin{tabular}{lccc}
\hline & Number of & Total u/grad & \% of u/grad \\
Institution & transfers & enrolments & transfers \\
& & & $3 \%$ \\
\hline Sub total highly selective institutions & 1,192 & 45,559 & $6 \%$ \\
Sub total moderately selective institutions & 1,399 & 21,584 & $4 \%$ \\
Total & 2,591 & 67,143 & \\
\hline
\end{tabular}

Source: Jacobs, Jim (2002) Colorado Commission on Higher Education, Data file. 
Table 4: ratio of transfer student admission rates of highly selective and moderately selective four-year institutions, Colorado, 2001

\begin{tabular}{lccc}
\hline Jurisdiction & $\begin{array}{c}\text { Highly selective } \\
\text { institutions }\end{array}$ & Moderately selective & Ratio of highly selective to \\
& institutions & moderately selective \\
\hline Colorado & $3 \%$ & $6 \%$ & $1: 2$ \\
\hline
\end{tabular}


Table 5: proportion of students at the highly selective and the moderately selective four-year public institutions who transferred from a community institution, Texas, 2000

\begin{tabular}{lccc}
\hline & Number of & Total u/grad & \% of u/grad \\
Institution & transfers & enrolments & enrols who are \\
& & & $15 \%$ \\
\hline Sub total highly selective institutions & 10,594 & 73,039 & $26 \%$ \\
Sub total moderately selective institutions & 61,968 & 237,029 & $23 \%$ \\
Total & 72,562 & 310,131 & \\
\hline
\end{tabular}

Source: Texas Higher Education Coordinating Board (2001) Report on the performance of Texas public universities. 
Table 6: ratio of transfer student admission rates of highly selective and moderately selective four-year institutions, Texas, 2000

\begin{tabular}{|c|c|c|c|}
\hline Jurisdiction & $\begin{array}{c}\text { Highly selective } \\
\text { institutions }\end{array}$ & $\begin{array}{c}\text { Moderately selective } \\
\text { institutions }\end{array}$ & $\begin{array}{c}\text { Ratio of highly selective to } \\
\text { moderately selective }\end{array}$ \\
\hline Texas & $15 \%$ & $26 \%$ & $1: 1.7$ \\
\hline
\end{tabular}


Table 7: proportion of undergraduate commencing students at the group of 8 Australian highly selective and other moderately selective universities who were admitted on the basis of a vocational education and training qualification, 2000

\begin{tabular}{lccc}
\hline Institution & $\begin{array}{c}\text { Admitted on basis } \\
\text { of VET }\end{array}$ & $\begin{array}{c}\text { Total bachelor } \\
\text { commencers }\end{array}$ & $\begin{array}{c}\% \text { of commencers who } \\
\text { are transfers }\end{array}$ \\
\hline Group of 8 universities & 1,028 & 45,359 & $2 \%$ \\
Dual sector universities & 1,231 & 24,602 & $5 \%$ \\
Other universities & 9,077 & 110,323 & $8 \%$ \\
TOTAL & 11,336 & 180,284 & $7 \%$ \\
\hline
\end{tabular}

Source: DETYA (2001) Higher education student statistics, 2000. 
Table 8: ratio of transfer student admission rates of highly selective and moderately selective four-year institutions, Australia, 2000

\begin{tabular}{lccc}
\hline $\begin{array}{l}\text { Jurisdiction } \\
\text { institutions }\end{array}$ & $\begin{array}{c}\text { Hoderately selective } \\
\text { institutions }\end{array}$ & $\begin{array}{c}\text { Ratio of highly selective to } \\
\text { moderately selective }\end{array}$ \\
\hline Australia & $2 \%$ & $8 \%$ & $1: 4$ \\
\hline
\end{tabular}


Table 9: ratio of transfer student admission rates of highly selective and moderately selective four-year institutions, Scotland, 2000

\begin{tabular}{lcc}
\hline Highly selective institutions & Moderately selective institutions & $\begin{array}{c}\text { Ratio of highly selective to } \\
\text { moderately selective }\end{array}$ \\
\hline $5 \%$ & $24 \%$ & $1: 5$ \\
\hline
\end{tabular}

Source: Gallacher (2003), table 7, p 12. 
Table 10: ratio of transfer student admission rates of highly selective and moderately selective four-year institutions, selected jurisdictions

\begin{tabular}{lccc}
\hline Jurisdiction & $\begin{array}{c}\text { Highly selective } \\
\text { institutions }\end{array}$ & $\begin{array}{c}\text { Moderately selective } \\
\text { institutions }\end{array}$ & $\begin{array}{c}\text { Ratio of highly selective to } \\
\text { moderately selective }\end{array}$ \\
\hline Scotland & $5 \%$ & $24 \%$ & $1: 5$ \\
Australia & $2 \%$ & $8 \%$ & $1: 4$ \\
California & $6.5 \%$ & $13 \%$ & $1: 2$ \\
Colorado & $3 \%$ & $6 \%$ & $1: 2$ \\
Texas & $15 \%$ & $26 \%$ & $1: 1.7$ \\
\hline
\end{tabular}

